\title{
Does The Implementation Of ERP Improve The Quality Of Accounting Information? Evidence From Chinese A-Share Listed Manufacturing Firms
}

Peiyu Ou, Xi'an Jiaotong University, China

Hong Zhao, Xi'an Jiaotong University, China

Zhao Zhou, Xi'an Jiaotong University, China

\begin{abstract}
Using the data of Chinese A-share listed manufacturing firms, the study explores the influence of ERP implementation on accounting information quality from reliability and relevance. Also, the study verifies the difference of the influence in firms which have different sizes and different ownership types. Compared with the firms not implementing ERP, accounting information quality of the firms implementing ERP improves significantly. In addition, the positive influence differs in firms of different sizes and different ownership types. In large-sized firms, ERP implementation has stronger influence on reliability of accounting information. In non-state-owned firms, ERP implementation has stronger influence on accounting information quality in respect to reliability and relevance. Our study supplies the new evidence to gauge the impact of ERP implementation on accounting information quality in an emerging economy context.
\end{abstract}

Keywords: ERP; Accounting Information Quality; Reliability; Relevance

\section{INTRODUCTION}

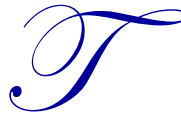

he quality of accounting information not only relates to interests of investors and stable development of capital market, but also affects the effective social resources allocation. The improvement of accounting information quality is a result of the combination of systematic and technical factors. Skok and Legge (2002) define ERP system as customizable and standard application software which integrates the core business processes and primary administrative functions of the firm. Firms implementing ERP systems have the chance to provide a strong technical support for accounting information collection, processing, transferring and reporting. Meanwhile, the automation process in ERP system avoids the excessive human intervention, which reduces the chances of opportunism behavior of management. On both the theoretical level and practical level, the implementation of ERP system has certain relevance with the improvement of accounting information quality. Previous ERP studies show that there is a positive relationship between ERP implementation and firms performance (Poston \& Grabski, 2001; Hitt, Wu \& Zhou, 2002; Hunton, Lippincott \& Reck, 2003).Few empirical studies have investigated the effect of ERP implementation on accounting information quality. The Chinese ERP market started in the late 1980s and the last decade has witnessed an unparalleled growth in investment in Chinese firms. China's ERP software revenue grew $12.8 \%$ in 2010, the highest of all countries, and for ERP services. China has one of the highest growth rates globally in 2010, at 9.5\% (Lo \& Tang, 2010). According to China Industrial Information Network (http://www.cnii.com.cn/) report, Chinese ERP software market China has reached RMB 40 billion in 2015. In the next few years, China will continue to lead in ERP software and service growth. In view of the wide application of ERP in Chinese firms, it is a good chance to examine the influence of ERP implementation on accounting information quality using the data of Chinese listed firms. 
The remainder of this paper is structured as follows. Section 2 reviews the literature. Section 3 presents theoretical background and develops the hypothesis. Section 4 describes research methodology. Section 5 shows the empirical results and section 6 discusses the findings and implications.

\section{LITERATURE REVIEW}

Existing studies related to the factors influencing accounting information quality is relatively mature. Generally, the factors can be divided into external macro factors and internal micro factors. The former mainly includes the perfection degree of accounting principles and relevant laws and regulations, the supervision of Securities Regulatory Commission, and cultural environment etc. (Ball, Kothari \& Robin, 2000; Jaggi \& Low, 2000; Leuz, Nanda \& Wysocki, 2003; Hope, 2003). The latter mainly includes the perfection degree of internal control system, corporate governance and political connection etc. (Gul \& Leung, 2004; Bushman, Chen \& Engel, 2004; Wang \& Claiborne, 2008).Among these factors, existing studies mainly focus on accounting principles, securities market and corporate governance, few studies have investigated the effect of internal technical factors (such as ERP) on effective implementation of accounting principles. Most of ERP studies have been explored the relationship between ERP implementation and firm performance and investigated the factors that influence ERP implementation (Poston \& Grabski,2001;Hitt et al.,2002;Hong \& Kim,2002;Hunton et al.,2003; Umble, Haft \& Umble, 2003; Nicolaou, 2004; Hendricks, Singhal \& Stratman, 2007). However, little is known about the influence of ERP implementation on accounting information quality. Most researchers believe that, in theory, ERP system can change the way of data processing, and realize the real-time acquisition, storage, and transmission of information. But the reliability of accounting information may decrease since the accountants can't control the accuracy of the raw data. Previous studies provide the evidence that there is a positive relationship between ERP implementation and the increase of timeliness of financial accounting information (Jensen \& Johnson 1999; Wah, 2000). Xu, Nord \& Brown (2002) find that the implementation of ERP may result in systematic risks and decline the reliability of data. Brazel and Dang(2008) examine how ERP implementation affect the extent to which earnings amounts release dates, show that implementation of ERP can increase accounting information relevance and decrease accounting information reliability. But the existing studies do not consider the effect of different ownership type because they mainly focus on the developed economies. In the emerging and transition economies such as China, ownership type is an important factor because there are different institutional constraints, business goals and level of IT assimilation in different ownership firms ( $\mathrm{Li}$, Chau \& Lai, 2010). As to ERP implementation in China, there are clear differences between privately-owned firms and stated-owned firms (Martinsons, 2004). In this study, we want to understand whether these empirical results of ERP implementation are applicable in different ownership firms in an emerging economy entity. Firm size is another important factor when examining the relationship between ERP implementation and firm performance. Hayes, Hunton \& Reck (2001) show that the market reaction to ERP implementation announcements is significantly more positive for small/healthy and large/unhealthy firms as opposed to small/unhealthy firms. Hunton et al. (2003) indicate a negative (positive) relationship between financial health and performance in large (small) firms. However, little research has been carried out which specifically concerns different firm size in ERP implementation and accounting information quality.

Following the previous study (Brazel \& Dang, 2008), our study develops a research model explaining ERP implementation and quality of accounting information. Accounting information reliability and relevance is measured by the absolute value of discretionary accruals and the reporting lag between fiscal year-end and the earnings release date (Jones, 1991). Using the data of Chinese A-share listed manufacturing firms, this study empirically tests the research model. Based on the findings, we find that ERP implementation is strongly associated with accounting information reliability and relevance. In addition, the positive influence demonstrates statistical differences across different sizes and different ownership types.

\section{THEORETICAL ANALYSIS AND HYPOTHESES DEVELOPMENT}

\subsection{Qualitative Qualities of Accounting Information}

Qualitative qualities imply the attributes that make the financial information useful to users. Qualitative qualities of accounting information play a major supporting role in the decision usefulness in accounting theory. The main qualities that make accounting information useful in decision-making is reliability and relevance. Both the two qualities are 
equally critical. If information is highly reliable but not relevant to the dicision, it is not useful. On the contrary, relevant information is valueless if it cannot be relied on.

Reliability means that the accounting information is truthful, accurate, complete and capable of being verified. The FASB's Conceptual Framework states, "Accounting information is reliable to the extent that users can depend on it to represent the economic conditions and events it purports to represent", and emphasizes three characteristics of reliability, that is representational faithfulness, verifiability, and neutrality. Accounting information should ensure a certain level of reliability to be useful to financial statement users, i.e. investors, creditors, and other users. Previous studies have pointed out that data limitations, model limitations and human errors and biases can reduce reliability because they could reduce representational faithfulness, verifiability, and neutrality (Maines \& Wahlen,2006).If one of the factors can be improved, accounting information reliability will be increased accordingly.

Relevance implies that accounting information must help the user to form, confirm or maybe revise a view in the decision-making process (Healy, Myers \& Howe, 2002).In order to make a difference in the decision process, information should have predictive value, feedback value and timeliness. Timeliness is a vital attribute of relevance. If information is either available when it is needed or become available quick after the reported events to allow its use in the decision process, it is timely and has value for future action. Although timeliness alone cannot make information relevant, the lack of timeliness can impair information relevance.

Therefore, we evaluate accounting information quality from two aspects-accounting information reliability and relevance. Further, the timeliness of accounting information is used to measure relevance.

\subsection{Hypotheses Development}

\subsubsection{The Reliability of Accounting Information}

As a kind of integrated information system, ERP embodies both the characteristics of computerized tool and advanced management concept and methods. The key feature of ERP system is integration, standardization, automation and lean management. The effectiveness of accounting process directly affects the quality of accounting information. Lack of support of information technology, it may be difficult for the traditional accounting process to satisfy the increasing information demand. ERP system integrates different modules seamlessly, uses the event-driven technology, and realizes the automation of accounting process. Automation means that ERP system can automatically gather data, generate accounting voucher, record ledgers and prepare financial statements. From that way, ERP system ensures the accuracy and authenticity of accounting information, and then improves the reliability of accounting information. Meanwhile, as data processing cost has been reduced greatly, accountants can choose a more reasonable accounting procedure, use a more accurate accounting method and make more objective and accurate accounting elements recognition, measurement to provide more reliable accounting information for users. Furthermore, due to ERP system's achievement in real time information sharing and mutual audit, the management's opportunism behavior to manage financial information is becoming more and more difficult. This will restrict the earnings management behavior of management, so as to improve accounting information reliability. For example, accounting policy choice is a popular method of earnings management. But in ERP system, accounting policy is a parameter data, once it is set in the background at the beginning, it is not easy to change. This will make the management more difficult to manipulate earnings through choosing accounting policy. ERP system records various decision-making behaviors objectively, reflects manager's operating performance quickly. Therefore, the earnings management behavior is more easily to be identified. In ERP system, financial statements can be prepared automatically and in real-time, thereby it reduces the management's time, opportunity and motivation to process data and manipulate earning before the financial report is prepared to some extent. Therefore, we put forward the following hypothesis:

H1: ERP implementation is positively associated with the reliability of accounting information.

\subsubsection{The Relevance of Accounting Information}

ERP system ensures the realization of accounting information's real-time acquisition, processing, transmission and output, provides more timely and effective accounting information for users. So, it is expected that the standardized 
and integrated ERP system can process transactions efficiently and shorten reporting lags(Hitt et al. 2002; Jacobs \& Bendoly, 2003; Brazel \& Dang, 2008).A reduction in reporting cycle time makes the firms to provide financial statements to external users in a more timely manner. In addition, ERP system collects financial information as well as non-financial information, monetary information as well as non-monetary information. Thus, it can provide rich and comprehensive enterprise-wide information for decision-making. Also, in ERP environment, the user can customize information based on their specific demand. So, the user's specific information demand can be satisfied, and ultimately relevance of accounting information is improved. Thus, we suggest the following hypothesis:

H2: ERP implementation is positively associated with the relevance of accounting information.

\subsubsection{Firm Size Effects}

ERP implementation is a very complicated system engineering. Its high cost, large investment and long implementation cycle make firm size a prerequisite for implementation of ERP successfully. Generally, large firms have higher levels of resources, or access to additional resources to afford the strain of ERP implementation than small firms. Despite a greater implementation cost because of operating size, Mabert, Soni \& Venkataramanan (2000) find that there are economies of scale working in large firms. Hunton et al. (2003) examine a significant interaction between financial health and firm size and in firms for ERP implementation. Especially, they report a negative (positive) relationship between financial health and performance for large (small) firms. Chinese studies find that ERP implementation will improve the operating capacity significantly, and the positive effect is more obvious in large firms (Sun \& Zhang, 2011). In addition, large firms tend to have more powerful strength, better management foundation and higher quality staff, thus they can get better return and higher quality of accounting information from ERP implementation. Since firm size is an important factor when examining the impact of ERP on accounting information quality, we propose the following hypothesis:

H3: Compared to small-sized firms, ERP implementation in large-sized firms has more positive effect in improving the reliability of accounting information.

H4: Compared to small-sized firms, ERP implementation in large-sized firms has more positive effect in improving the relevance of accounting information.

\subsubsection{Ownership Type Effects}

We want to understand whether the relationships in hypothesis 1 and 2 perhaps differ across different ownership firms. In emerging and transition economies, ownership type is usually identified as significant factors explaining differences between state-owned and non-state-owned firms ( $\mathrm{Li}$ et al.2010). The classification of ownership type in transition economies is diversified. Following previous studies (Peng, Tan \& Tong, 2004; Zhao, Flynn \& Roth, 2006), this paper classified all firms as state-owned firms and non-state-owned firms includes privately owned, foreign owned and joint venture. Using Chinese data, Li et al. (2010) shows that ownership type had influenced IT assimilation significantly. Martinsons (2004) states that successful ERP implementation in Chinese firms tend to be affected by top management, planned ahead of time, and tightly controlled during implementation. Also, he finds eight fundamental difference in ERP implementations between China's state-owned enterprises (SOEs) and private ventures (PVs). The detailed difference is illustrated in Table 1. 
Table 1. Eight Differences in ERP implementation between China's SOEs and PVs (Martinsons,2004)

\begin{tabular}{|c|c|c|}
\hline & SOES & PVs \\
\hline Primary project aims & Cutting costs and automating processes & $\begin{array}{l}\text { Improving competitiveness through process } \\
\text { streamlining and integration }\end{array}$ \\
\hline Role of top management & Tendency to delegate ERP responsibilities & $\begin{array}{l}\text { Hands-on leadership to demonstrate } \\
\text { commitment }\end{array}$ \\
\hline Role of steering committee & $\begin{array}{l}\text { Much more centralized management } \\
\text { structure, a small group of senior managers } \\
\text { tended to control ERP project }\end{array}$ & $\begin{array}{l}\text { More frequent meetings and sharper focus on } \\
\text { problem resolution }\end{array}$ \\
\hline Role of consultants & $\begin{array}{l}\text { Limited experience with consultants, rarely } \\
\text { engaged outside help, and tend to be IT } \\
\text { generalists }\end{array}$ & $\begin{array}{l}\text { Greater reliance on outside help and more } \\
\text { emphasis on ERP-specific expertise }\end{array}$ \\
\hline Scope of implementation & Similar efforts spawned functional conflicts & $\begin{array}{l}\text { Broader and more cross-functional ERP } \\
\text { application }\end{array}$ \\
\hline Pace of implementation & $\begin{array}{l}\text { Tendency to rely on personal relationships } \\
\text { and implemented in phases }\end{array}$ & Faster and less gradual implementation \\
\hline Implementation problems & $\begin{array}{l}\text { More data maintenance problems after } \\
\text { adopting ERP }\end{array}$ & Less frequent and less serious problems \\
\hline Evaluation and outcomes & $\begin{array}{l}\text { Achieve more cost reductions, and rare } \\
\text { quality or supply chain enhancement }\end{array}$ & $\begin{array}{l}\text { Undertake more systematic evaluation and } \\
\text { control, and achieve more substantial quality } \\
\text { and supply chain improvements }\end{array}$ \\
\hline
\end{tabular}

Mascarenhas(1989) states that different ownership firms are supposed to execute different strategies, goals and business behaviors. In general, state-owned firms tend to implement conservative strategies and have a limited ability to assimilate new IT. And, unlike state-owned firms, non-state-owned firms can fully control resources and are more likely to implement positive strategies for IT assimilation and diffusion (Peng et al. 2004; Zhao et al. 2006).Further, the Chinese government encouraged firms to investment on information technology to promote industrialization, in turn, stimulate informatization. Some state-owned firms implemented ERP systems in response to the government's informatization advocacy, but they slowed down or even stopped the use of ERP modules to manage business activities after implementation. In order to explore the differences effect of ERP implementation on the quality of accounting information across different ownership firms, we have the following hypothesis:

H5: Compared to state-owned firms, ERP implementation in non-state-owned firms has more positive effect in improving the reliability of accounting information.

H6: Compared to state-owned firms, ERP implementation in non-state-owned firms has more positive effect in improving the relevance of accounting information.

\section{RESEARCH METHODOLOGY}

\subsection{Variable Measurement}

\subsubsection{Dependent Variable}

\subsubsection{Reliability of Accounting Information}

Reliability is an essential characteristic for accounting information to be useful for decision making. The FASB's Conceptual Framework states, "reliability represents the extent to which the information is unbiased, free from error, and representationally faithful." Following previous studies, this paper measures the reliability of accounting information with ADSDA which is the absolute value of discretionary accruals calculated from the cross-sectional modified Jones model (Dechow, Sloan \& Sweeney, 1995; Brazel \& Dang, 2008). The difference of actual total accruals with predicted total accruals from an accrual prediction model represent discretionary accruals, or accounting information reliability. The bigger ABSDA is assumed to the greater space for earning management and the less reliable accounting information in financial report. 


\subsubsection{Relevance of Accounting Information}

Relevance implies accounting information must have predictive value, feedback value and timeliness. Timeliness is one important attribute of relevance. Only timely information may be relevant. A reduction in reporting cycle time means the firm is more likely to provide financial information to external users in a more timely fashion. Following the prior literature (Haw, Qi \& Wu, 2000; Brazel \& Dang,2008), financial reporting lag time $(L A G T)$, the difference between the firm's actual financial statement disclosure date and fiscal year-end, is used to measure the timeliness of accounting information.

\subsubsection{Independent Variable}

$E R P$, which measures whether ERP is implemented in a firm, is a dummy variable with value 1 for ERP implementation and 0 otherwise.

\subsubsection{Moderating Variable}

Firm size (SIZE) is a dummy variable with value 1 for the natural logarithm of total assets is bigger than median of all sample and 0 otherwise.

Ownership Type $(S O E)$ is a dummy variable with value 1 for SOEs and 0 otherwise.

\subsubsection{Control Variable}

We incorporate some control variables in the models, which is addressed in previous studies that might affect discretionary accruals and reporting lag (Whittred, 1980; Whittred \& Zimmer, 1984;Dechow et al. 1995; Peasnell, Pope \& Young, 1999; Brazel \& Dang,2008).

(1) Ownership concentration (FIRST), which is measured as the share proportion of the largest shareholder.

(2) Duality (DUAL), which is a dummy variable with value 1 for duality of CEO and chairman and 0 otherwise.

(3) Independent directors ratio (IND), which is measured as the proportion of independent directors.

(4) Growth of firm (GROWTH), which is the ratio of operating income difference between current and previous period to operating income of previous period.

(5) Operating cash flow $(O C F)$, which is the ratio of operating net cash flow to total assets.

(6) Leverage ( $L E V)$, which is the ratio of total debt to total assets.

(7) Ratio of equity $(R O E)$, which is the ratio of net profit to total owners' equity.

(8) Audit opinion $(A O)$, which is a dummy variable with value 1 for standard unqualified audit opinion and 0 otherwise.

(9) Loss or not (LOSS), which is a dummy variable with value 1 for loss and 0 otherwise.

(10) Industry, which is a dummy variable based on China Securities Regulatory Commission (CSRC) industry classification codes (first digit).

(11) Year, which is a trend variable with value 0 for 2004 and incremented by 1 for next each year.

\subsection{Model Specification}

To explore the influence of ERP implementation on quality of accounting information and the moderating effect of firm size and ownership type, we construct models 1 to 6 , of which models 1 and 2 test hypothesis 1 and 2 .

$$
\begin{aligned}
& A B S D A_{i t}=\beta_{0}+\beta_{1} E R P_{i t}+\beta_{2} A O_{i t}+\beta_{3} \text { GROWTH }_{i t}+\beta_{4} O C F_{i t}+\beta_{5} \text { LOSS }_{i t}+\beta_{6} \text { DUAL }_{i t}+ \\
& \beta_{7} I_{\text {IND }} \sum_{j=1}^{9} \beta_{j+7} \text { Industry }_{i t j}+\sum_{k=1}^{7} \beta_{k+16} \text { Year }_{i t k}+\varepsilon_{i t}
\end{aligned}
$$




$$
\begin{aligned}
& L A G T_{i t}=\beta_{0}+\beta_{1} E R P_{i t}+\beta_{2} L_{O S S} S_{i t}+\beta_{3} L E V_{i t}+\beta_{4} A O_{i t}+\beta_{5} R O E_{i t}+\beta_{6} I N D_{i t}+ \\
& \beta_{7} \text { FIRST } \sum_{j=1}^{9} \beta_{j+7} \text { Industry }_{i t j}+\sum_{k=1}^{7} \beta_{k+16} \text { Year }_{i t k}+\varepsilon_{i t}
\end{aligned}
$$

Further, to test hypothesis 3 and 4, we verify the signs and significance of SIZE and ERP*SIZE in model 3 and model 4 respectively:

$$
\begin{aligned}
& A B S D A_{i t}=\beta_{0}+\beta_{1} E R P_{i t}+\beta_{2} S I Z E_{i t}+\beta_{3} E R P_{i t} * S I Z E_{i t}+\beta_{4} A O_{i t}+\beta_{5} G R O W T H_{i t}+\beta_{6} O C F_{i t}+ \\
& \beta_{7} \text { LOSS }_{i t}+\beta_{8} D U A L_{i t}+\beta_{9} I N D_{i t} \sum_{j=1}^{9} \beta_{j+9} \text { Industry }_{i t j}+\sum_{k=1}^{7} \beta_{k+18} \text { Year }_{i t k}+\varepsilon_{i t} \\
& L A G T_{i t}=\beta_{0}+\beta_{1} E R P_{i t}+\beta_{2} S I Z E_{i t}+\beta_{3} E R P_{i t} * S I Z E_{i t}+\beta_{4} L O S S_{i t}+\beta_{5} L E V_{i t}+\beta_{6} A O_{i t}+\beta_{7} R O E_{i t}+ \\
& \beta_{8} I N D_{i t}+\beta_{9} F_{I R S T}+\sum_{j=1}^{9} \beta_{j+7} \text { Industry }_{i t j}+\sum_{k=1}^{7} \beta_{k+16} \text { Year }_{i t k}+\varepsilon_{i t}
\end{aligned}
$$

And to test hypothesis 5 and 6, we verify the signs and significance of SOE and ERP*SOE in model 5 and model 6 respectively:

$$
\begin{aligned}
& A B S D A_{i t}=\beta_{0}+\beta_{1} E R P_{i t}+\beta_{2} S O E_{i t}+\beta_{3} E R P_{i t} * S O E_{i t}+\beta_{4} A O_{i t}+\beta_{5} \text { GROWTH }_{i t}+\beta_{6} \text { OCF }_{i t}+ \\
& \beta_{7} \text { LOSS }_{i t}+\beta_{8} D U A L_{i t}+\beta_{9} I N D_{i t} \sum_{j=1}^{9} \beta_{j+9} \text { Industry }_{i t j}+\sum_{k=1}^{7} \beta_{k+18} \text { Year }_{i t k}+\varepsilon_{i t} \\
& \text { LAGT }_{i t}=\beta_{0}+\beta_{1} E R P_{i t}+\beta_{2} S O E_{i t}+\beta_{3} E R P_{i t} * S O E_{i t}+\beta_{4} \text { LOSS }_{i t}+\beta_{5} L E V_{i t}+\beta_{6} A O_{i t}+\beta_{7} R O E_{i t}+ \\
& \beta_{8} I N D_{i t}+\beta_{9} \text { FIRST }_{i t}+\sum_{j=1}^{9} \beta_{j+9} \text { Industry }_{i t j}+\sum_{k=1}^{7} \beta_{k+18} \text { Year }_{i t k}+\varepsilon_{i t}
\end{aligned}
$$

\subsection{Sample Selection}

The full sample was identified from Chinese A-share manufacturing firms listed on the Main Board of Shanghai and Shenzhen Stock Exchanges from 2004 to 2014.In China, ERP implementation announcements are voluntary information disclosure. First, following previous studies (Hayes et al.2001; Nicolaou, 2004), we used a combination research keywords of "ERP+implement," "ERP+adopt," or "ERP+contract"(in Chinese) and the name of each listed A-shares manufacturing firms. Second, for the firms in which ERP implementation information cannot be found in the first phase, we searched the term of "ERP" in the full text of financial report and internal control self-assessment report of the firms. Third, the website of ERP vendors and consultancy firm was searched for any success case of ERP implementation. Of these samples, some are deleted due to lack of exact implementation year and financial data, leaving the following sample as Table 2. The data were acquired from the China Stock Market and Accounting Research (CSMAR) database. Some data were manually collected from the annual financial reports of listed firms and the website of ERP software vendor and consulting firm.

Table 2. Sample size

\begin{tabular}{l|c|c|c|c|c|c|c|c|c|c|c|c|}
\hline \multicolumn{1}{|c|}{ Year } & $\mathbf{2 0 0 4}$ & $\mathbf{2 0 0 5}$ & $\mathbf{2 0 0 6}$ & $\mathbf{2 0 0 7}$ & $\mathbf{2 0 0 8}$ & $\mathbf{2 0 0 9}$ & $\mathbf{2 0 1 0}$ & $\mathbf{2 0 1 1}$ & $\mathbf{2 0 1 2}$ & $\mathbf{2 0 1 3}$ & $\mathbf{2 0 1 4}$ & Total \\
\hline $\begin{array}{l}\text { Number of firms } \\
\text { implementing ERP }\end{array}$ & 86 & 99 & 107 & 132 & 138 & 150 & 165 & 175 & 302 & 442 & 551 & 2047 \\
\hline $\begin{array}{l}\text { Number of firms not } \\
\text { implementing ERP }\end{array}$ & 223 & 354 & 352 & 304 & 320 & 340 & 408 & 614 & 639 & 701 & 720 & 4975 \\
\hline Total & 309 & 453 & 459 & 436 & 458 & 490 & 573 & 789 & 941 & 1143 & 1271 & 7322 \\
\hline
\end{tabular}




\section{THE EMPIRICAL RESULTS AND ANALYSIS}

\subsection{Descriptive Statistics}

Table 3 shows the descriptive statistics of the main variable for 7322 samples.

Table 3. Descriptive statistics of the main variables for whole sample

\begin{tabular}{l|c|c|c|c|c}
\hline \multicolumn{1}{c|}{ Variable } & Mean & Std.Dev & Minimum & Median & Maximum \\
\hline ABSDA & 0.0156 & 0.1189 & -2.0856 & 0.0100 & 1.9721 \\
\hline LAGT & 87.8943 & 21.8066 & 26 & 89 & 120 \\
\hline ERP & 0.4335 & 0.4956 & 0 & 0 & 1 \\
\hline SIZE & 0.5000 & 0.5001 & 0 & 0 & 1 \\
\hline SOE & 0.4960 & 0.5000 & 0 & 0 & 1 \\
\hline
\end{tabular}

Table 3 shows that mean value, minimum value and maximum value of ABSDA is $0.0156,-2.0856$ and 1.972, respectively. On the whole, the sample firms make both positive earnings management and negative earnings management. The median is 0.0100 , less than mean of 0.0156 , means that the degree of earnings management in most sample firms is below the average level. We also find mean of LAGT is 87.8943 days, indicating that the sample firms usually disclose financial reports in an average of three months after the end of the fiscal year. The minimum and maximum LAGT is 26 days and 120 days, the standard deviation is 21.8066 days. So, there is a great difference of financial report disclosure date between different firms. The mean ERP is 0.4335 , showing that $43.35 \%$ of the listed manufacturing firms have implemented ERP system. The mean SOE is 0.4960 , indicating that $49.60 \%$ of the sample firms are state-owned firms. Since different ownership of samples have similar size, the effectiveness of the moderating effects of SIZE and SOE could be ensured.

\subsection{Correlation Analysis}

Spearman correlation coefficient is used to test the relationship between dependent variable and independent variables (Due to limited space, the result is omitted). ABSDA and LAGT are significantly related to ERP, ERP*SIZE, ERP*SOE and other control variables. This means ERP implementation will influence the reliability and relevance of accounting information, also appropriate control variables are selected in the model. In addition, the correlation coefficient between ERP*SIZE, ERP and SIZE is more than 0.6. Similar problems also occur between ERP*SOE, ERP and SOE. In order to eliminate the multicollinearity, we will centralize ERP, SIZE and SOE before the subsequent regression analysis.

\subsection{Regression Result}

Table 4 reports OLS regression estimates for Models 1-6. Model 1 includes ERP and control variables to examine the relationship between ERP implementation and ABSDA. As expected, implementation of ERP is positively to ABSDA at 5\% significance level. Hypothesis 1 is supported. Specially, coefficient of ABSDA and LOSS is positive at 1\% significance level. It means that earnings management behavior exists in loss-making firms in loss-making year, which indicates the reliability of accounting information is low in the year. In model 3 and 5, we test hypothesis 3 and 5 by introducing SIZE and SOE as a moderator of the association between ERP and reliability of accounting information. In model 3, coefficient of interaction term ERP*SIZE is negative at $10 \%$ significance level, indicating that the positive relationship between ERP implementation and accounting information reliability is magnified in large-sized firms. Thus, hypothesis 3 is supported. In model 5, SOE is negatively related to ABSDA and interaction term ERP*SOE is positive related to ABSDA at $1 \%$ significance level, reflecting that stated-owned firms could generate higher reliable accounting information. But ERP implementation in stated-owned firms plays a less positive role on the accounting information reliability than non-stated-owned firms. Hypothesis 5 is supported.

Regression results of model 2 shows that coefficient of ERP implementation is negative at $1 \%$ significance level, indicating that ERP implementation firms could have shorter financial reporting lag time and generate higher relevant 
accounting information, supporting our hypothesis 2.Besides, LAGT is negatively related to control variable AO at $1 \%$ significance level, showing that the firms which obtain the standard unqualified audit opinion have shorter financial report delay(Whittred,1980). Coefficient of ROE is significantly negative at $1 \%$ significance level, indicating that firms with higher profitability could have a shorter financial report delay. Model 4 and 6 introduce SIZE and SOE as a moderator to verify the relationship between ERP and relevance of accounting information. In model 4, LAGT and SIZE are positive related at 10\% significance level, LAGT is negatively related to interaction item ERP*SIZE but is not significant. So hypothesis 4 is not supported. The reason may be that, although large-sized firms have more money to afford the high cost of ERP implementation than small-sized firms, they also meet more complex environment, more difficulties to proceed business process reengineering and more time to improve data integration and conversion. Compared with large-sized firms, small-sized firms have more flexible organization and faster information processing speed. Therefore, there is no significant difference between the positive roles of ERP system on accounting information relevance in different scale firms. Regression results of model 6 shows that coefficient of ERP*SOE is positive at $10 \%$ significance level. It indicates that ERP implementation in non-state-owned firms could make more positive impact on accounting information relevance. Thus, hypothesis 6 is supported.

Table 4. Regression results for model 1-6

\begin{tabular}{|c|c|c|c|c|c|c|}
\hline & $A B S D A$ & $A B S D A$ & $A B S D A$ & $L A G T$ & $L A G T$ & $L A G T$ \\
\hline & Model 1 & Model 3 & Model 5 & Model 2 & Model 4 & Model 6 \\
\hline ERP & $\begin{array}{l}-0.0034^{* *} \\
(-2.07)\end{array}$ & $\begin{array}{l}-0.0004 \\
(-0.14)\end{array}$ & $\begin{array}{l}-0.0198^{* * *} \\
(-4.08)\end{array}$ & $\begin{array}{l}-1.7913^{* * *} \\
(-2.72)\end{array}$ & $\begin{array}{l}-1.2771^{*} \\
(-1.90)\end{array}$ & $\begin{array}{l}-1.0780^{*} \\
(-1.68)\end{array}$ \\
\hline SIZE & & $\begin{array}{l}0.0025 \\
(0.84)\end{array}$ & & & $\begin{array}{l}1.3311^{*} \\
1.90\end{array}$ & \\
\hline ERP*SIZE & & $\begin{array}{l}-0.0080^{*} \\
(-1.87)\end{array}$ & & & $\begin{array}{l}-0.2429 \\
(-0.19)\end{array}$ & \\
\hline SOE & & & $\begin{array}{l}-0.0259^{* * *} \\
(-5.63)\end{array}$ & & & $\begin{array}{l}-0.0063 \\
(-0.45)\end{array}$ \\
\hline ERP*SOE & & & $\begin{array}{l}0.0174^{* * *} \\
(2.72)\end{array}$ & & & $\begin{array}{l}0.0007^{*} \\
(1.72)\end{array}$ \\
\hline AO & $\begin{array}{l}-0.0153^{* *} \\
(-2.23)\end{array}$ & $\begin{array}{l}-0.0205^{* *} \\
(-2.27)\end{array}$ & $\begin{array}{l}-0.0089 \\
(-0.65)\end{array}$ & $\begin{array}{l}-16.7033^{* * *} \\
(-6.00)\end{array}$ & $\begin{array}{l}-14.3367^{* * *} \\
(-5.08)\end{array}$ & $\begin{array}{l}-16.4559^{* * *} \\
(-5.89)\end{array}$ \\
\hline GROWTH & $\begin{array}{l}0.0495^{* * *} \\
(11.49)\end{array}$ & $\begin{array}{l}0.0321^{* * *} \\
(13.02)\end{array}$ & $\begin{array}{l}0.0937^{* * *} \\
(11.69)\end{array}$ & & & \\
\hline OCF & $\begin{array}{l}-0.1928^{* * *} \\
(-13.78)\end{array}$ & $\begin{array}{l}-0.2905^{\text {*** }} \\
(-18.89)\end{array}$ & $\begin{array}{l}-0.2076^{* * *} \\
(-7.93)\end{array}$ & & & \\
\hline LOSS & $\begin{array}{l}0.0413^{* * *} \\
(9.32)\end{array}$ & $\begin{array}{l}0.0553^{\text {*** }} \\
(9.44)\end{array}$ & $\begin{array}{l}0.0240^{* * *} \\
(3.06)\end{array}$ & $\begin{array}{l}6.8153^{* * *} \\
(4.18)\end{array}$ & $\begin{array}{l}7.0337^{* * *} \\
(4.16)\end{array}$ & $\begin{array}{l}6.2065^{* * *} \\
(3.97)\end{array}$ \\
\hline DUAL & $\begin{array}{l}0.0034 \\
(1.63)\end{array}$ & $\begin{array}{l}0.0067^{* *} \\
(2.39)\end{array}$ & $\begin{array}{l}0.0001 \\
(0.03)\end{array}$ & & & \\
\hline IND & $\begin{array}{l}-0.0248 \\
(-1.15)\end{array}$ & $\begin{array}{l}-0.0455^{* *} \\
(-2.13)\end{array}$ & $\begin{array}{l}-0.0323 \\
(-0.99)\end{array}$ & $\begin{array}{l}-2.1648 \\
(-0.27)\end{array}$ & $\begin{array}{l}-1.3995 \\
(-0.15)\end{array}$ & $\begin{array}{l}-4.6567 \\
(-0.75)\end{array}$ \\
\hline LEV & & & & $\begin{array}{l}1.0403 \\
(0.52)\end{array}$ & $\begin{array}{l}5.8072^{* * *} \\
(2.93)\end{array}$ & $\begin{array}{l}5.3323^{* * *} \\
(3.10)\end{array}$ \\
\hline ROE & & & & $\begin{array}{l}-36.8772^{* * *} \\
(-8.92)\end{array}$ & $\begin{array}{l}-11.6339^{* * *} \\
(-4.77)\end{array}$ & $\begin{array}{l}-34.3578^{* * *} \\
(-8.29)\end{array}$ \\
\hline FIRST & & & & $\begin{array}{l}-4.1643^{*} \\
(-1.85)\end{array}$ & $\begin{array}{l}-4.7446^{* *} \\
(-2.07)\end{array}$ & $\begin{array}{l}-1.7889 \\
(-0.86)\end{array}$ \\
\hline _cons & $\begin{array}{l}0.1211^{* * *} \\
(10.01)\end{array}$ & $\begin{array}{l}0.0854^{* * *} \\
(5.91)\end{array}$ & $\begin{array}{l}0.0953^{* * *} \\
(5.06)\end{array}$ & $\begin{array}{l}80.8520^{* * *} \\
(9.77)\end{array}$ & $\begin{array}{l}103.1037^{* * *} \\
(19.47)\end{array}$ & $\begin{array}{l}108.7946^{* * *} \\
(24.89)\end{array}$ \\
\hline $\begin{array}{l}\text { Control Year } \\
\text { and Industry }\end{array}$ & Yes & Yes & Yes & Yes & Yes & Yes \\
\hline $\mathbf{N}$ & 7322 & 7322 & 7322 & 7322 & 7322 & 7322 \\
\hline $\operatorname{Adj} . R^{2}$ & 0.1326 & 0.1369 & 0.2028 & 0.0616 & 0.0937 & 0.0670 \\
\hline F & $24.27^{* * *}$ & $25.40^{* * *}$ & $38.25^{* * *}$ & $12.14^{* * *}$ & $16.54^{* * *}$ & $13.72^{* * *}$ \\
\hline
\end{tabular}

Note: 1. Figures in brackets is t value;

2. *,**,***indicate significant at the $10 \%, 5 \%, 1 \%$ levels, respectively.

3. In model 3 to 6, ERP, SIZE and SOE have been centralized. VIF (variance inflation factor) is lower than the critical value of 10, indicating that the multicollinearity problem has been ruled out. 


\section{MAJOR FINDINGS AND IMPLICATIONS}

Using a sample of 7322 Chinese A-share listed manufacturing firms from 2004 to 2014, this study examines the relationship between ERP implementation and reliability and relevance of accounting information, as well as the moderating effects of firm size and ownership type on the relationship. Different from previous studies, the result finds a positive relationship between ERP implementation and reliability and relevance of accounting information. In terms of firm size, large-sized firms have more resources and external funding support to afford the high cost of ERP implementation. Usually, they have a relatively higher management ability and possess high-quality employees, so ERP implementation can obtain better return in improving accounting information reliability. But large-sized firms may also face more difficulty to assimilate ERP system. So, compared to small-sized firms, there are no evidence that ERP implementation in large-sized firms could lead to significant reductions in reporting lags and improvement of accounting information relevance. In terms of ownership types, non-stated-owned firms regard ERP implementation as an opportunity of carrying out "best business process". Their managers tend to be more willing to take participates in ERP projects. Business process reengineering can get more support from employees and managers. Therefore, in non-stated-owned firms, ERP implementation has stronger influence on accounting information quality.

The findings of this study have implications for improvement of accounting information quality of firms. First, business process should be reengineered firstly when a firm is planning to implement ERP system and expecting effective and efficient use. By redesigning the existing accounting business process thoroughly and eliminating "nonvalue-added" activities in accounting business process, ERP implementation will improve the accuracy, authenticity and timeliness of accounting information firstly so as to promote the quality of accounting information. Second, this finding could provide available guidance for firms to promote accounting information quality in ERP implementation across different size and ownership in the transition economies. Firms should pay attention to own conditions influencing ERP implementation effect. For small-sized firms, they should adopt a prudent policy to implement ERP system since its high cost, long time and complexity. The firms need to ensure that there are sufficient funds to guarantee ERP system launched and assimilated successfully. For state-owned firms, they should profoundly realize the importance of accounting business process reengineering in ERP implementation. By motivating and inspiring employees and managers to cooperate with the accounting business process restructuring, ERP system is very helpful in improving accounting information quality.

There are also several limitations to the study. First, the announcements of ERP implementation are voluntarily disclosed by Chinese listed firms. The sample is selected by different alternative methods. So, there may be a selection bias because only the firms which hope to be searched or be known by the public are contained in the sample. Second, compared to developed economies, the successful rate of ERP implementation in Chinese firms was lower because of complex social, cultural and political context (Xue, Liang, Boulton \& Snyder, 2005). It should be noted that firms' decision to implementation ERP does not make sure that ERP system will be routinized in the business processes in the long run. Many Chinese firms fail to maximize employees' effective usage beyond the initial implementation of ERP. So, the sample firms maybe have unsuccessful implementations, future studies may need to make sure the assimilation of ERP of the sample firms to better understand the impacts of ERP on accounting information quality. Third, there are many variables influencing accounting information quality. In consideration of the unique attributes of ERP systems, this study has examined some variables found to be important in the previous studies. Future research can be conducted on this and can extend the study by an inclusion of other possible variables in the different economic contexts.

\section{ACKNOWLEDGMENTS}

This study is supported by Humanities and Social Science Fund of Ministry of Education in China (14YJC630102).

\section{AUTHOR BIOGRAPHIES}

Peiyu Ou, associate professor in School of Management, Xi' an Jiaotong University, China. She received her Ph.D. in Management Science and Engineering, from Xi'an Jiaotong University in 2006. Her research interests focus on information technology and management accounting change. E-mail: oupeiyu@mail.xjtu.edu.cn (Corresponding author). 
Hong Zhao, associate professor in School of Management, Xi' an Jiaotong University, China. She received her Ph.D. in Accounting, from Xi'an Jiaotong University in 2006. Her research interests focus on performance measurement and banking.

Zhao Zhou, graduate student in School of Management, Xi'an Jiaotong University, China.

\section{REFERENCES}

Ball, R., Kothari, S. P., \& Robin, A. (2000). The effect of international institutional factors on properties of accounting earnings. Journal of Accounting and Economics, 29(1), 1-51.

Brazel, J. \& Dang, L. (2008). The effect of ERP system implementations on the management of earnings and earnings release dates. Journal of Information Systems, 22(2), 1-21.

Bushman, R., Chen, Q., \& Engel, E. (2004). Financial accounting information, organizational complexity and corporate governance systems. Journal of Accounting and Economics, 37(2), 167-201.

Dechow, P. M., Sloan R. G.1 \& Sweeney, A. P. (1995).Detecting earnings management. The Accounting Review, 70(2), $193-225$.

Gul, F. A., \& Leung, S. (2004). Board leadership, outside directors' expertise and voluntary corporate disclosures. Journal of Accounting and Public Policy, 23(5), 351-379.

Haw, I., Qi, D., \& Wu,W. (2000). Timeliness of annual report releases and market reaction to earnings announcements in an emerging capital market: The case of China. Journal of InternationalFinancial Management and Accounting, 11(2), 108-131.

Hayes, D. C., Hunton, J. E., \& Reck, J. L. (2001). Market reaction to ERP implementation announcements. Journal of Information Systems, 15(1), 3-18.

Healy, P. M., Myers, S. C. \& Howe, C. D. (2002). R \& D accounting and the tradeoff between relevance and objectivity. Journal of Accounting Research, 40(3), 677-710.

Hendricks, K. B., Singhal,V. R., \& Stratman, J. K. (2007).The impact of Enterprise Systems on corporate performance: A study of ERP, SCM, and CRM system implementations. Journal of Operations Management, 25(1), 65-82.

Hitt, L. M., Wu, D. J. \& Zhou, X. (2002). Investment in Enterprise Resource Planning: Business impact and productivity measures. Journal of Management Information Systems, 19(1), 71-98.

Hong, K., \& Kim, Y. (2002). The critical success factors for ERP implementation: An organizational fit perspective. Information \& Management, 40(1), 25-40.

Hope, O. K. (2003). Firm-level disclosures and the relative roles of culture and legal origin. Journal of International Financial Management \& Accounting, 14(3), 218-248.

Hunton, J. E., Lippincott, B., \& Reck, J. L. (2003). Enterprise Resource Planning systems: Comparing firm performance of adopters and nonadopters. International Journal of Accounting information systems, 4(3), 165-184.

Jacobs, F. R., \& Bendoly, E. (2003). Enterprise Resource Planning: Developments and directions for operations management research. European Journal of Operational Research, 146(2), 233-240.

Jaggi, B., \& Low, P. Y. (2000). Impact of culture, market forces, and legal system on financial disclosures. The International Journal of Accounting, 359(4), 495-519.

Jensen, R., \& Johnson, R. (1999). The Enterprise Resource Planning system as a strategic solution. Information Strategy, 15(4), 28-33.

Jones, J. J. (1991). Earnings management during import relief investigations. Journal of Accounting Research, 29(2), $193-228$.

Leuz, C., Nanda, D., \& Wysocki, P. D. (2003). Earnings management and investor protection: An international comparison. Journal of Financial Economics, 69(3), 505-527.

Li, D. H., Chau, P. Y. K., \& Lai, F.(2010). Market orientation, ownership type, and E-business assimilation: Evidence from Chinese firms. Decision Sciences, 41(1), 115-145.

Lo, T., \& Tang, T. T. (2010). Magic quadrant for ERP service providers. Gartner RAS Core Research Note, G00205999.

Mabert, V. A., Soni, A., \& Venkataramanan, M. A. (2003). Enterprise Resource Planning: Managing the implementation process. European Journal of Operational Research, 146(2), 302-314.

Maines, L., \& Wahlen, J. (2006). The nature of accounting information reliability: Inferences from archival and experimental research. Accounting Horizons, 20(4), 399-425.

Martinsons, M. G. (2004). ERP in China: one package, two profiles. Communication of the ACM, 47(7), 65-68.

Mascarenhas, B. (1989). Domains of stated-owned, privately held, and publicly traded companies in international competition. Administrative Science Quarterly, 34(4), 582-597.

Nicolaou, A. I. (2004). Firm performance effects in relation to the implementation and use of Enterprise Resource Planning systems. Journal of Information Systems, 18(2), 79-105.

Peasnell, K., Pope, P., \& Young. S. (1999). Outside directors, board effectiveness, and abnormal accruals. General Information, 88(35), 561-562.

Peng, M. W., Tan, J., \& Tong, T. (2004). Ownership types and strategic groups in an emerging economy. Journal of Management Studies, 41(7), 1105-1129. 
Poston, R. \& Grabski, S. (2001). Financial impacts of Enterprise Resource Planning implementations. International Journal of Accounting Information Systems, 2(4),271-294.

Skok, W. \& Legge, M. (2002). Evaluating Enterprise Resource Planning (ERP) systems using an interpretive approach. Knowledge and Process Management, 9(2), 72-82.

Sun. Y. P., \& Zhang, Z. H. (2011). Which kind of companies will give better financial performance after ERP implementation?evidence from Chinese manacturing listed firms(in Chinese ). Economic Science, 3, 105-117.

Umble, E. J., Haft, R. R., \& Umble, M. M. (2003). Enterprise Resource Planning: Implementation procedures and critical success factors. European Journal of Operational Research, 146(2), 241-257.

Wah, L. (2000). Give ERP a chance. Management Review, 89(3), 20-24.

Wang, K., \& Claiborne, M. C. (2008). Determinants and consequences of voluntary disclosure in an emerging market: Evidence from China. Journal of International Accounting, Auditing and Taxation, 17(1), 14-30.

Whittred, G. (1980). Audit qualification and the timeliness of corporate annual reports. Accounting Review, 55(4), 563-577.

Whittred, G., \& Zimmer, I. (1984). Timeliness of financial reporting and financial distress. Accounting Review, 59(2), $287-295$.

Xu, H., Nord, J. H., \& Brown, N. (2002). Data quality issues in implementing an ERP. Industrial Management \& Data Systems, 102(1), 47-58.

Xue,Y., Liang H., Boulton, W. R., \& Snyder, C. A. (2005). ERP implementation failures in China: Case studies with implementations for ERP vendors. International Journal of Production Economics, 97(3), 279-295.

Zhao, X., Flynn, B. B., \& Roth, A.V. (2006). Decision sciences research in China: A critical review and research agenda foundations and overview. Decision Sciences, 37(4), 451-496. 